\title{
Effect of skim milk powder and sucrose on quality and storage stability of mango leather
}

\author{
Adnan Khaliq ${ }^{1}$, Moazzam Rafiq Khan², Samreen Ahsan², Muhammad Farhan Jahangir \\ Chughtai $^{3}$, Muhammad Nadeem ${ }^{*}$ and Ayesha Aslam²
}

\author{
${ }^{1}$ Institute of Human Nutrition and Dietetics Gulab Devi Educational Complex, Ferozpur Road,Lahore - Pakistan. \\ ${ }^{2}$ National Institute of Food Science \& Technology, Faculty of Food Nutrition \& Home Sciences, University of Agriculture, \\ Faisalabad-Pakistan. \\ ${ }^{3}$ Department of Environmental Sciences, COMSATS Institute of Information Technology, Vehari-Pakistan. \\ ${ }^{*}$ Corresponding author. Email: mnadeem11@gmail.com
}

Copyright (C) 2018 Khaliq et al. This article remains permanently open access under the terms of the Creative Commons Attribution License 4.0, which permits unrestricted use, distribution, and reproduction in any medium, provided the original work is properly cited.

Received 15th March, 2018; Accepted 23rd May, 2018

\begin{abstract}
Mango has marvelous flavour, eye-catching color, fragrance, appealing taste and high nutritional value which make it one of the best fruit. Pakistan produced tons of mango varieties with exceptional taste, aroma and flavor. Despite the massive production, huge volume of produced mangoes are wasted due to post harvest losses. These losses can be curtailed through value addition of mangoes such as fruit leathers. Fruit leathers are the dehydrated fruit-based products normally eaten as candy or snacks and presented as flexible stripes or sheets. In this study leather (dried product) from mango pulp was prepared using cabinet drying with different concentrations of skim milk powder and sucrose. After vacuum packaging, leather was stored at room temperature. The results showed decreasing trend in $\mathrm{pH}(3.81$ to 3.73$)$, moisture contents (16.67 to 12.39), ascorbic acid (36.41 to 18.52). reducing sugars (13.64 to 13.13) while the non-reducing sugars increased (43.81 to 45.49 ) over time. Mineral contents were slightly varied during storage interval. Overall acceptability of the mango leather was also good and could be accepted within 75 days.
\end{abstract}

Key words: Cabinet drying, fruit leathers, mangoes, marvelous flavor, nutritional value, overall acceptability, vacuum packaging.

\section{INTRODUCTION}

Fruits and vegetables contain high amount of antioxidants, anthocyanin, carotenoids, phenolic compounds, vitamins and minerals consequently having a greater value regarding health benefits (Wall, 2006). Mango (belonging to the genus Mangifera) is a seasonal fruit native to Pakistan, India, Bangladesh, China, Brazil, South and Central America, Caribbean and Central Africa, Australia and other parts of Asia. In the International market, Pakistan is the 4th major mango producing country (Memon, 2016). Mango is the second largest fruit grown after citrus in Pakistan (Khan et al., 2008). Its encompasses bountiful vitamins ( $\mathrm{A}, \mathrm{C}$, and $\mathrm{E})$ and minerals such as calcium ( $\mathrm{Ca}$ ) and magnesium $(\mathrm{Mg})$ and entices consumers owing to these marvelous dietary nutrients. It most popular, nutritionally rich fruits with unique flavor, fragrance, taste, and heath promoting qualities making it a common ingredient in new functional foods often labeled "super fruits". Fruits and vegetables reduce the risk of cardiovascular diseases, cancers of pharynx, lungs, colon, mouth and stroke (Riboli and Norat, 2003). Mango fruits also contain thiamin, riboflavin, and niacin that owns antioxidant properties and help to prevent certain types of disorders. However, people suffering from renal disorders should avoid its consumption as it owns huge amount of magnesium which intake is constrained in these patients. 
Res. J. Food Sci. Nutr.

Every year a huge amount of mango is wasted due to poor management and post-harvest losses. These losses can be minimized through value addition and making different products like mango leather, jam, jellies, squashes various other products. Different emerging technologies like modified atmosphere packaging, edible coating, high pressure processing and cold storage can also minimized the post-harvest losses. Number of other mangoes preservation techniques are being practicing in the international market, including canned mango, mango puree, mango juice, dried cracker mango and mango jam (Naz, 2012).

Fruit leather is dehydrated product having shiny, soft rubbery texture and sweet in taste that possesses an extended shelf life. Fruit leather is made from a single fruit or blend or mixture of different fruits (Naz, 2012). They may be eaten as snack foods or as a healthy alternative to boiled sweets, as topping of cakes, in ice cream and manufacturing of flavored cookies (Azeredo et al., 2009). Immature mangoes can be used to develop leathers as functional ingredients for daily intake. Fruit leathers are fruit rolls and a rich source of carbohydrates, vitamins and minerals. Its appearance is like leather after drying process that's why leather name is given to this dried product. The moisture content is about 15 to $20 \%$ after drying, which increases the shelf life up to 6 months (Kaushal et al., 2013). In the same way, mango leathers contain low protein content (1 to 2\%) (Pushpa et al., 2006). To augment the protein content and nutritive value of mango leather, skim milk powder is added (Diamante et al., 2014). Sucrose is added at different concentrations to increase the sweetness and caloric level of the end product.

Cabinet drying process has established significant notice for making leathers to diminish energy expenditure and perk up food quality (Hawlader et al., 2006). Some dehydrating methods have disadvantages to the product that may be due to unrestrained processing conditions such as the overheating that would lead to textural damage to the product (Izli et al., 2017). The present research project was premeditated to appraise the potential effects of skim milk powder and sucrose at different concentration on quality of mango leather during storage. Skim milk powder and sucrose were added as hydrocolloids which not only reduced drying time of mango leather as well as augmented the caloric and protein contents. The objectives of present study were to increase utilization of mango fruit through development of leather and also to monitor the quality characteristics of mango leather by adding skim milk powder and sucrose as a functional ingredient during storage.

\section{MATERIALS AND METHODS}

The study was conducted at National Institute of Food Science and Technology, University of Agriculture,
Faisalabad. Fully ripened mangoes were procured from the local market of Faisalabad. Mangoes were washed, peeled and then passed through a pulper to get mango pulp. Drying was carried out using hot air in a cabinet dryer procedure as described by Gujral and Khanna, 2002. Skim milk powder and sucrose were added in pulp at different concentration according to the following treatment plans.

Mango pulp $(500 \mathrm{~g})$ was added to $2 \mathrm{~cm}$ deep aluminium trays (Table 1). Drying was carried out using hot air at a temperature of $60^{\circ} \mathrm{C}$ and velocity of $3.5 \mathrm{~m} / \mathrm{s}$ in a cabinet dryer. The cabinet drier was adjusted to the selected temperature at least 30 minutes before drying. Trays were weighed at every $15 \mathrm{~min}$ intervals. The aluminum trays were smeared with very thin layer of refined vegetable oil to prevent the sticking of mango leather on surface of trays after drying. The mango leather was sealed in polyethylene pouches and stored at room temperature for storage study.

\section{Physical analysis}

Mango leather was analyzed for its physical $(\mathrm{pH}$, colour, texture, Total soluble solids) and chemical analysis (Moisture, Acidity, Minerals, Sugars) as a function of storage. The $\mathrm{pH}$ was calculated with the help of digital $\mathrm{pH}$ meter (AOAC, 2006). Colour was determined with the help of colorimeter (Color Test-II Neuhaus Neotec). The measurements were recorded under constant lighting condition (Piga et al., 2005) using a white tile control ( $L^{*}$ $\left.97.46, a^{*} 0.02, b^{*} 1.72\right)$. Texture analysis of leather was determined using texture analyzer ((TA-XT 2PLUS) stable Microsystem, Surrey, UK) interfaced with the computer (Tontul and Topuz, 2017).

\section{Chemical analysis}

Moisture content of mango leather was determined by following the procedure in AOAC (2006). Acidity was determined according to the procedure described by Rababah et al., (2011). $2 \mathrm{~g}$ sample was grounded with 10 $\mathrm{mL}$ distilled water and add few drops of phenolphthalein indicator, get filtrate using the whatman filter paper and titrated against $0.1 \mathrm{~N} \mathrm{NaOH}$ solution until light pink color appeared. Acidity was calculated by using the standard formula as given.

Acidity $(\%$ anhydrous CA $)=\frac{0.009 \times \text { volume of } \mathrm{NaOH} \text { used } \times 100}{\text { Weight of sample }}$

Minerals like, $\mathrm{Na}$, iron and $\mathrm{K}$ were determined by using flame photometer and atomic absorption by following the procedures described in AOAC (2006). Standard solutions of $20,40,60,80$ and $100 \mathrm{ppm}$ were used for $\mathrm{Na}, \mathrm{Fe}$ and $\mathrm{K}$. The dilution factor for all minerals was 100 . The concentrations of minerals recorded in terms of "ppm" 
Table 1. Treatment plane of mango leather.

\begin{tabular}{lccc}
\hline Treatments & Mango pulp (g) & Sucrose (\%) & Skim milk powder (\%) \\
\hline $\mathrm{T}_{0}$ & 500 & 0 & 0 \\
$\mathrm{~T}_{1}$ & 500 & 3 & 3 \\
$\mathrm{~T}_{2}$ & 500 & 6 & 6 \\
$\mathrm{~T}_{3}$ & 500 & 9 & 9 \\
\hline
\end{tabular}

$\mathbf{T}_{0}=$ Control; $\mathbf{T}_{1}=3 \%$ sucrose \& Skim milk powder; $\mathbf{T}_{2}=6 \%$ sucrose \& Skim milk powder; $\mathbf{T}_{3}=$ $9 \%$ sucrose \& Skim milk powder.

were converted to milligrams $(\mathrm{mg})$ of the minerals by multiplying the ppm with dilution factor and dividing by 1000 as

MW $=\frac{\text { Absorbance }(\mathrm{ppm}) \times \text { dry wt. } \times \mathrm{D}}{\text { Weight of sample } \times 1000}$

Where $\mathrm{MW}=$ Mineral determination and $\mathrm{D}=$ Dilution factor .

\section{Sugar determination}

\section{Preparation of reagent}

Sugar was determined by the Lane and Eynon method described by Kumar et al. (2005). Fehling's A solution was made by dissolving $34.649 \mathrm{~g} \mathrm{CuSO}_{4} .5 \mathrm{H}_{2} \mathrm{O}$ in distilled water using volumetric flask to make final volume $500 \mathrm{~mL}$. Fehling's B solution was prepared by dissolving $173 \mathrm{~g}$ of Potassium sodium tartate and $50 \mathrm{~g} \mathrm{NaOH}$ in distilled water and made volume $500 \mathrm{~mL}$ and stored for 2 to 3 days so that solution become stable. Methylene blue indicator was prepared by dissolving $1 \mathrm{~g}$ of methylene blue dye in 100 $\mathrm{mL}$ distilled water. $20 \mathrm{~g}$ Lead. $\mathrm{A}$. $\mathrm{Pb}_{6}\left(\mathrm{C}_{2} \mathrm{H}_{3} \mathrm{O}_{2}\right)_{2} \cdot 3 \mathrm{H}_{2} \mathrm{O}$ was dissolved in $100 \mathrm{~mL}$ distilled water for lead acetate preparation. One gram $(1 \mathrm{~g})$ of Phenolphthalein dye was dissolved in $100 \mathrm{~mL}$ of distilled water. Potassium oxalate was prepared by dissolving $165 \mathrm{~g}$ of potassium oxalate $\left(\mathrm{K}_{2} \mathrm{C}_{2} \mathrm{O} .4 \mathrm{H}_{2} \mathrm{O}\right)$ in distilled water and diluted up to $500 \mathrm{~mL}$. The potassium oxalate and lead acetate act as filter aid and make solution clear from fiber to give quick color.

\section{Reducing sugars}

Total sugar was estimated by dissolving mango leather in distilled water and added $10 \mathrm{~g}$ of citric acid in the sample and heated for 10 minute and then cooled it. 2 to 3 drops of phenolphthalein were added as indicator in the flask containing sample. $0.1 \mathrm{~N} \mathrm{NaOH}$ was added until the pink color appeared and then added $0.1 \mathrm{~N} \mathrm{HCl}$ until the disappearance of pink color. The sample was filled in burrette for further analysis. A solution of $10 \mathrm{~mL}$ volume was prepared by adding $5 \mathrm{~mL}$ of Fehling's $A$ and $5 \mathrm{~mL}$ of Fehling's B solution in a conical flask and boiled and when boiling was started, 2 to 3 drops of methylene blue indicator were added and allowed to stay for 2 minutes. It was boiled again for 2 minute and titrated it against sample. $50 \mathrm{~mL}$ of juice was taken in a conical flask and the same procedure was followed for total sugars determination.

\section{Non-reducing sugars estimation}

Non-reducing sugars can be calculated by subtracting the reducing sugar from the total sugar as follows:

$\%$ Non-reducing sugars= $\%$ Total sugars - - $\%$ Reducing sugars

\section{Vitamin C (Ascorbic acid)}

The Ascorbic acid was determined according to the method described by Ordóñez-Santos et al. (2017). $1 \mathrm{~mL}$ of $0.01 \%$ of ascorbic acid mixed with $1.5 \mathrm{~mL}$ of oxalic acid and titrated against $0.04 \%$ dye to get the reference standard reading and $R_{1}$ reading was noted until light pink color appeared. For determination of ascorbic acid in sample, blended sample of mango leather was taken and made to a volume of $100 \mathrm{~mL}$ by adding $0.4 \%$ oxalic acid solution. It was filtered to remove fibrous material. $10 \mathrm{~mL}$ of filtered sample was taken and $15 \mathrm{~mL}$ of oxalic acid was added to it. Then titrated it against dye and noted the volume of dye used $(R)$.

\section{Statistical analysis}

The data was interpreted by two-way analysis of variance (ANOVA) using Statistics 8.1 software package as described by Steel et al. (1997)

\section{RESULTS AND DISCUSSIONS}

The storage study of mango leather vacuum packages was carried out for 75 days stored at room temperature. The statistical data indicated that total soluble solids were non significantly affected by treatments, storage days and also non-significant by their interactions (Tables 2 and 3 ). 
Table 2. Effect of storage days (means) on physico-chemical analysis

\begin{tabular}{|c|c|c|c|c|c|c|c|c|c|c|c|c|c|c|}
\hline \multirow[b]{2}{*}{ Days } & \multirow{2}{*}{$\begin{array}{l}\mathrm{pH} \\
(\%)\end{array}$} & \multirow{2}{*}{$\begin{array}{c}\text { Acidity } \\
(\%)\end{array}$} & \multirow[b]{2}{*}{ TSS (\%) } & \multirow{2}{*}{$\begin{array}{c}\text { Moisture } \\
(\%)\end{array}$} & \multirow[b]{2}{*}{ Texture } & \multicolumn{3}{|c|}{ Color } & \multicolumn{2}{|c|}{ Sugar (\%) } & \multirow{2}{*}{$\begin{array}{c}\text { Ascorbic Acid } \\
(\mathrm{mg} / 100 \mathrm{~g})\end{array}$} & \multicolumn{3}{|c|}{ Minerals $(\mathrm{mg} / 100 \mathrm{~g}$ ) } \\
\hline & & & & & & $L^{*}$ & $a^{*}$ & $b^{*}$ & $\begin{array}{l}\text { Reducing } \\
\text { sugars }\end{array}$ & $\begin{array}{c}\text { Non-reducing } \\
\text { sugars }\end{array}$ & & $\mathrm{Fe}$ & $\mathrm{K}$ & $\mathrm{Na}$ \\
\hline 0 & $3.81^{\mathrm{A}}$ & $0.76^{C}$ & $67.37^{\mathrm{A}}$ & $16.67^{A}$ & $9.52^{\mathrm{D}}$ & $47.83^{\mathrm{A}}$ & $8.83^{A}$ & $38.51^{\mathrm{A}}$ & $13.64^{\mathrm{A}}$ & $43.81^{\mathrm{AB}}$ & $36.41^{\mathrm{A}}$ & $8.89^{A}$ & $182.12^{\mathrm{A}}$ & $24.03^{\mathrm{A}}$ \\
\hline 15 & $3.76^{A B}$ & $0.78^{B}$ & $67.52^{\mathrm{A}}$ & $15.68^{B}$ & $9.58^{\mathrm{BC}}$ & $45.64^{B}$ & $8.01^{\mathrm{C}}$ & $36.74^{B}$ & $13.61^{\mathrm{A}}$ & $44.21^{\mathrm{AB}}$ & $32.91^{B}$ & $8.92^{\mathrm{A}}$ & $180.93^{A}$ & $23.91^{A}$ \\
\hline 30 & $3.75^{\mathrm{AB}}$ & $0.78^{B}$ & $67.67^{\mathrm{A}}$ & $14.78^{\mathrm{C}}$ & $9.91 \mathrm{CD}$ & $43.14 \mathrm{C}$ & $7.70^{\mathrm{D}}$ & $35.43 \mathrm{C}$ & $13.44^{\mathrm{AB}}$ & $44.76^{\mathrm{AB}}$ & $29.46^{C}$ & $8.93^{A}$ & $182.18^{A}$ & $24.11 \mathrm{~A}$ \\
\hline 45 & $3.76^{\mathrm{AB}}$ & $0.79 \mathrm{~B}$ & $62.88^{B}$ & $13.79^{D}$ & $9.94^{\mathrm{B}}$ & $41.35^{C}$ & $7.78^{\mathrm{D}}$ & $33.91^{\mathrm{D}}$ & $13.29^{B C}$ & $42.18^{B}$ & $24.21^{\mathrm{D}}$ & $8.89^{A}$ & $181.3^{\mathrm{A}}$ & $23.15^{\mathrm{A}}$ \\
\hline 60 & $3.75^{\mathrm{AB}}$ & $0.80^{\mathrm{AB}}$ & $67.69^{A}$ & $13.25^{\mathrm{E}}$ & $9.98^{\mathrm{D}}$ & $39.47 \mathrm{E}$ & $8.2^{\mathrm{B}}$ & $32.99 \mathrm{E}$ & $13.2^{C}$ & $45.13^{A B}$ & $21.41 \mathrm{E}$ & $8.9^{\mathrm{A}}$ & $181.31^{\mathrm{A}}$ & $24.07^{\mathrm{A}}$ \\
\hline 75 & $3.73^{\mathrm{B}}$ & $0.81^{\mathrm{A}}$ & $68.18^{\mathrm{A}}$ & $12.39 \mathrm{~F}$ & $10.51^{\mathrm{A}}$ & $37.42^{F}$ & $8.10^{C}$ & $33.16^{\mathrm{E}}$ & $13.13^{C}$ & $45.79^{\mathrm{A}}$ & $18.52^{\mathrm{F}}$ & $8.97^{\mathrm{A}}$ & $182.25^{\mathrm{A}}$ & $24.22^{\mathrm{A}}$ \\
\hline
\end{tabular}

*Means carrying different letter are significantly different from each other, whereas means carrying same letters are non-significant.

Table 3. Effect of treatments (means) on physico-chemical analysis

\begin{tabular}{|c|c|c|c|c|c|c|c|c|c|c|c|c|c|c|}
\hline \multirow[b]{2}{*}{ Treatments } & \multirow[b]{2}{*}{$\mathrm{pH}(\%)$} & \multirow{2}{*}{$\begin{array}{c}\text { Acidity } \\
(\%)\end{array}$} & \multirow[b]{2}{*}{ TSS (\%) } & \multirow{2}{*}{$\begin{array}{c}\text { Moisture } \\
(\%)\end{array}$} & \multirow[b]{2}{*}{ Texture } & \multicolumn{3}{|c|}{ Color } & \multicolumn{2}{|c|}{ Sugar $(\%)$} & \multirow[b]{2}{*}{$\begin{array}{l}\text { Ascorbic Acid } \\
(\mathrm{mg} / 100 \mathrm{~g})\end{array}$} & \multicolumn{3}{|c|}{ Minerals $(\mathrm{mg} / 100 \mathrm{~g})$} \\
\hline & & & & & & $L^{*}$ & $a^{*}$ & $b^{*}$ & $\begin{array}{c}\text { Reducing } \\
\text { sugars }\end{array}$ & $\begin{array}{c}\text { Non-reducing } \\
\text { sugars }\end{array}$ & & $\mathrm{Fe}$ & K & $\mathrm{Na}$ \\
\hline TO & $3.75^{\mathrm{AB}}$ & $0.80^{\mathrm{A}}$ & $65.47^{\mathrm{A}}$ & $15.31^{\mathrm{A}}$ & $10.07^{\mathrm{A}}$ & $49.40^{\mathrm{A}}$ & $8.15^{\mathrm{B}}$ & $36.27^{\mathrm{A}}$ & $13.51^{\mathrm{A}}$ & $44.43^{\mathrm{A}}$ & $30.81^{\mathrm{A}}$ & $8.96^{\mathrm{A}}$ & $182.15^{\mathrm{A}}$ & $24.01^{\mathrm{A}}$ \\
\hline T1 & $3.79^{A}$ & $0.80^{\mathrm{A}}$ & $67.04^{B}$ & $14.30^{\mathrm{B}}$ & $9.74^{\mathrm{B}}$ & $42.75^{\mathrm{B}}$ & $7.91^{\mathrm{C}}$ & $35.56^{\mathrm{B}}$ & $13.27^{\mathrm{B}}$ & $44.16^{\mathrm{A}}$ & $26.34^{B}$ & $8.89^{A}$ & $180.26^{A}$ & $23.92^{\mathrm{A}}$ \\
\hline T2 & $3.73^{\mathrm{B}}$ & $0.77^{\mathrm{B}}$ & $68.41^{\mathrm{B}}$ & $14.15^{\mathrm{B}}$ & $9.77^{\mathrm{B}}$ & $40.10^{c}$ & $7.99 \mathrm{C}$ & $35.44^{B}$ & $13.36^{A B}$ & $45.02^{A}$ & $26.71^{B}$ & $8.90^{\mathrm{A}}$ & $182.27^{\mathrm{A}}$ & $24.06^{\mathrm{A}}$ \\
\hline T3 & $3.77^{\mathrm{AB}}$ & $0.78^{B}$ & $66.61^{\mathrm{B}}$ & $13.95^{C}$ & $9.92^{\mathrm{AB}}$ & $37.65^{\mathrm{D}}$ & $8.73^{\mathrm{A}}$ & $33.24^{C}$ & $13.39^{A B}$ & $43.65^{\mathrm{A}}$ & $24.75^{C}$ & $8.92^{\mathrm{A}}$ & $182.04^{\mathrm{A}}$ & $23.67^{\mathrm{A}}$ \\
\hline
\end{tabular}

*Means carrying different letter are significantly different from each other, whereas means carrying same letters are non-significant.

It is evident from Table 2 that the mean values of total soluble solids varied from 65.47 to 68.41 in all the treatments. TSS ranged from 65.11 to 65.86 in $\mathrm{T}_{0}, 67.12$ to $67.84,68.11$ to $68.70,69.15$ to 70.32 in $T_{1}, T_{2}$ and $T_{3}$ respectively. Maximum TSS 68.41 was observed in $T_{2}$ and minimum 65.47 was observed in $T_{0}$ during the storage. The similar result about TSS has been reported by Manisha et al. (2011) who studied formulation and acceptability of foam mat dried sea buckthorn (Hippophae salicifolia) leather and he observed the increasing trend in TSS during storage. Similar trend of TTS was explained by Kaushal et al. (2013) during the storage study.
$\mathrm{pH}$ was not significantly affected by treatments, storage days and by their interactions. It is evident from Table 3 that $\mathrm{pH}$ varies from 3.75 to 3.79 in all the treatments. pH ranged from 3.80 to 3.69 in $\mathrm{T}_{0}$, 3.81 to $3.75,3.83$ to 3.70 and 3.79 to 3.74 in $T_{1}, T_{2}$ and $\mathrm{T}_{3}$ respectively. Maximum pH 3.79 was observed in $T_{1}$ and minimum was observed at 3.75 in $\mathrm{T}_{0}$. The minimum value of $\mathrm{pH}$ was observed 3.75 at 60 days storage and maximum was observed at 0 day storage (Table 2). The $\mathrm{pH}$ value decreased during the storage days. The similar results were reported by Moreno et al. (2004), who studied the effect of osmotic dehydration on chillian papaya. Dea et al. (2010) reported that $\mathrm{pH}$ decreased during storage study. Furthermore, Moreno et al. (2004), reported that the variation in $\mathrm{pH}$ values was due to environmental stress.

The result obtained for colour indicated that the colour was darkened during storage of fruit leather. The statistical analysis indicated that $L$ value was highly significant in treatments, storage days and their interactions. Data regarding the mean values of $L$ varied from 37.65 to 49.40 in all the treatments. $L$ value ranged from 46.65 to 53.23 in $T_{0}, 37.85$ to $48.56,33.75$ to 46.07 and 31.45 to 43.45 in $\mathrm{T}_{1}, \mathrm{~T}_{2}$ and $T_{3}$ respectively. Maximum $L$ value was 49.40 observed in $T_{0}$ which shows that color of $T_{0}$ was brighter than all other treatments and minimum 
37.65 was observed in $T_{3}$. The statistical analysis indicated that $a^{*}$ value was highly significant in treatments, storage days and their interactions. Data regarding the mean values of $\mathrm{a}^{*}$ varied from 7.91 to 8.37 in all the treatments. The minimum value 7.91 was observed in $T_{2}$ and maximum 8.37 was observed in $T_{3}$. The maximum value 8.83 was observed at 0 day and minimum 7.70 was at 30 days. The values ranged from 7.67 to 9.23 in $T_{0}, 7.36$ to $8.48,7.19$ to 8.68 and 7.98 to 8.91 in $T_{1}, T_{2}$ and $T_{3}$ respectively. Statistical results indicated that $b^{*}$ value was highly significant affected in treatments, storage days and their interactions. Mean values of $b^{*}$ varied from 33.24 to 35.41 in all the treatments. $b^{*}$ value ranged from 33.12 to 41.11 in $T_{0}, 32.61$ to $39.97,33.01$ to 37.75 and 32.31 to 35.19 in $T_{1}, T_{2}$ and $T_{3}$ respectively. Maximum $b$ value 36.27 was observed in $T_{0}$ which shows that color of $T_{0}$ was brighter than all other treatments and minimum value 33.24 was observed in $T_{3}$ which shows that color of $T_{3}$ was darker than all other treatments. The similar trend that the $\mathrm{L}$, $\mathrm{a}$ and $\mathrm{b}$ value decreased during storage has been reported by Henriette et al. (2006) which means that the color is darkening during storage of fruit leather. Azeredo et al., (2006) also reported similar trend in color analysis during storage studies.

The statistical analysis of texture depicted that texture is highly significant affected in days, while non-significant in treatment and their interactions. The mean values of texture varied from 9.74 to 10.07 in all the treatments. Texture value ranged from 9.75 to 10.70 in $\mathrm{T}_{0}, 9.36$ to $10.50,9.43$ to 10.45 and 9.40 to 10.40 in $T_{1}, T_{2}$ and $T_{3}$ respectively. Maximum texture value 10.07 was observed in $T_{0}$ and minimum value 9.74 was observed in in $T_{2}$ which shows that texture of $T_{0}$ was more firmness than all other treatments and minimum value 9.74 was observed in $T_{2}$. The variance in texture value in $\mathrm{T}_{3}$ was observed very low as compared to the other treatments during storage.

The statistical analysis indicated that moisture contents were highly significant in treatments, storage days and their interactions. It is evident from the mean values of moisture contents varied from 13.95 to 15.31 in all the treatments. Moisture contents decreased from 10.70 to 9.75 in $T_{0}, 10.50$ to $9.36,10.45$ to $9.43,10.40$ to 9.40 in $T_{1}$, $\mathrm{T}_{2}$ and $\mathrm{T}_{3}$ respectively. Maximum moisture contents 15.31 was observed in $\mathrm{T}_{0}$ and minimum 13.95 moisture contents was observed in $T_{3}$. Moisture contents were decreased from 0 to 75 days of storage interval. The results reported by Manisha et al. (2011) who studied acceptability of foam mat dried seabuck-thorn are in opposite that may be due to the storage temperature as temperature in Pakistan is more than room temperature on average but Kaushal et al. (2013) reported the similar results to present study.

The statistical data showed that acidity was highly significantly affected in treatments and storage days and non-significant by their interactions. From the mean values of acidity, it is evident that it varies from 0.77 to 0.80 in all the treatments. Acidity ranged from 0.78 to 0.83 in $\mathrm{T}_{0}, 0.76$ to $0.84,0.74$ to 0.80 and 0.76 to 0.78 in $T_{1}, T_{2}$ and $T_{3}$ respectively. Maximum acidity 0.80 was observed in $T_{0}$ and $T_{1}$, and minimum acidity 0.77 was observed in $T_{2}$. The variance in acidity in $T_{3}$ as observed is 0.78 low as compared to the other treatments during storage. The acidity value increases during the storage. Similar result was obtained in the study of Durrani and Verma (2011) on the study of preparation and quality evaluation of honey Amla Murabba.

The statistical data from analysis of variance showed that iron, potassium and sodium were not significantly affected by storage days, treatments and interactions of days and treatments. The mean values of iron varied from 8.89 to 8.96 in all the treatments. Iron ranged from 8.93 to 8.99 in $\mathrm{T}_{0}, 8.78$ to $8.98,8.85$ to 8.95 and 8.87 to 8.95 in $\mathrm{T}_{1}$, $\mathrm{T}_{2}$ and $\mathrm{T}_{3}$ respectively. Maximum iron concentration 8.96 was observed in $\mathrm{T}_{0}$ and minimum iron concentration 8.89 was observed in $T_{2}$. The variation in iron concentration in $\mathrm{T}_{0}$ is observed to be very low as compared to the other treatments during storage. Data regarding the mean values of potassium varied from 180.26 to 182.27 in all the treatments. Potassium ranged from 182.10 to 182.21 in $\mathrm{T}_{0}$, 178.37 to $182.15,182.22$ to 182.33 and 181.02 to 182.30 in $T_{1}, T_{2}$ and $T_{3}$ respectively. Maximum potassium concentration 182.27 was observed in $\mathrm{T}_{2}$ and minimum potassium concentration 180.26 was observed in $T_{1}$. The variance in potassium concentration in $T_{0}$ was observed to be very low as compared to the other treatments during storage. In case of sodium, the mean values varied from 23.67 to 24.06 in all the treatments. Sodium ranged from 23.58 to 24.16 in $\mathrm{T}_{0}, 23.70$ to $24.20,23.93$ to 24.17 and 20.68 to 24.34 in $T_{1}, T_{2}$ and $T_{3}$ respectively. Maximum sodium concentration 24.06 was observed in $T_{2}$ and minimum sodium concentration 23.67 was observed in $T_{3}$. The variance in sodium concentration in $T_{0}$ was observed to be very low as compared to the other treatments during storage. The similar concentrations of minerals were reported by the Chukwuka et al. (2013) who studied nutritional and compositional considerations for new varieties of papaya.

The statistical data from analysis showed that reducing sugars were not significantly affected by treatments, storage days and their interactions. Similarly, in case of non-reducing sugars statistical data from analysis showed that non-reducing sugars were also non significantly affected by treatments, storage days and their interactions. The mean values of reducing sugars varied from 13.27 to 13.51 in all the treatments. Reducing sugars ranged from 12.98 to 14.02 in $\mathrm{T}_{0}, 12.96$ to $13.56,13.21$ to 13.49 and 13.30 to 13.50 in $T_{1}, T_{2}$ and $T_{3}$ respectively. Maximum reducing sugars concentration 13.51 was observed in $T_{0}$ and minimum reducing sugars 13.27 concentrations was observed in $T_{1}$ during storage. Mean values of nonreducing sugars varied from 43.65 to 45.02 in all the treatments. Non-reducing sugars ranged from 42.65 to 45.89 in $\mathrm{T}_{0}, 43.56$ to $45.48,44.32$ to 45.75 and 35.02 to 46.03 in $T_{1}, T_{2}$ and $T_{3}$ respectively. Maximum non-reducing sugars concentration 45.02 was observed in $T_{2}$ and 
Table 4. Effect of storage intervals (means) on organoleptic properties of mango leather

\begin{tabular}{lccccc}
\hline Days & Color & Flavor & Texture & Taste & Overall acceptability \\
\hline 0 & $6.50^{\mathrm{A}}$ & $5.75^{\mathrm{A}}$ & $6.17^{\mathrm{A}}$ & $5.3^{\mathrm{A}}$ & $6.25^{\mathrm{A}}$ \\
15 & $6.17^{\mathrm{AB}}$ & $6.00^{\mathrm{A}}$ & $6.08^{\mathrm{B}}$ & $5.3^{\mathrm{A}}$ & $6.00^{\mathrm{A}}$ \\
30 & $5.83^{\mathrm{AB}}$ & $5.67^{\mathrm{A}}$ & $6.00^{\mathrm{B}}$ & $5.1^{\mathrm{A}}$ & $6.00^{\mathrm{A}}$ \\
45 & $5.67^{\mathrm{B}}$ & $5.75^{\mathrm{A}}$ & $6.17^{\mathrm{A}}$ & $5.2^{\mathrm{A}}$ & $6.08^{\mathrm{A}}$ \\
60 & $6.08^{\mathrm{AB}}$ & $5.75^{\mathrm{A}}$ & $6.08^{\mathrm{B}}$ & $5.3^{\mathrm{A}}$ & $6.17^{\mathrm{A}}$ \\
75 & $5.75^{\mathrm{B}}$ & $6.00^{\mathrm{A}}$ & $6.08^{\mathrm{B}}$ & $5.3^{\mathrm{A}}$ & $6.08^{\mathrm{A}}$ \\
\hline
\end{tabular}

${ }^{*}$ Means carrying different letter are significantly different from each other, whereas means carrying same letters are non-significant.

Table 5. Effect of Treatments (means) on organoleptic properties of mango leather.

\begin{tabular}{lccccc}
\hline Treatments & Color & Flavor & Texture & Taste & Overall acceptability \\
\hline T0 & $6.22^{\mathrm{A}}$ & $6.06^{\mathrm{A}}$ & $6.00^{\mathrm{B}}$ & $5.1^{\mathrm{B}}$ & $6.00^{\mathrm{A}}$ \\
T1 & $6.11^{\mathrm{AB}}$ & $5.61^{\mathrm{A}}$ & $6.06^{\mathrm{B}}$ & $5.0^{\mathrm{B}}$ & $6.06^{\mathrm{A}}$ \\
T2 & $5.61^{\mathrm{B}}$ & $5.83^{\mathrm{A}}$ & $6.22^{\mathrm{A}}$ & $5.9^{\mathrm{C}}$ & $6.00^{\mathrm{A}}$ \\
T3 & $6.60^{\mathrm{AB}}$ & $5.78^{\mathrm{A}}$ & $6.17^{\mathrm{A}}$ & $4.9^{\mathrm{D}}$ & $6.33^{\mathrm{A}}$ \\
\hline
\end{tabular}

*Means carrying different letter are significantly different from each other, whereas means carrying same letters are non-significant.

minimum non-reducing sugars concentration 43.65 was observed in $\mathrm{T}_{3}$ during the storage period. The variance in non-reducing sugars concentration in $\mathrm{T}_{3}$ was observed to be very low as compared to the other treatments during storage. The similar increasing trend during the storage days was reported by Manisha et al. (2011) who studied acceptability of foam mat dried seabuck-thorn leather. Similar findings were also reported by Kaushal et al. (2013).The effect of storage on physico-chemical parameters of mango leather are represented in Figures 1 to 4 .

The statistical data from analysis showed that vitamin C was highly significantly affected in treatments, storage days while non-significant in their interactions. It is evident from the mean values that vitamin $C$ varied from 24.75 to 30.81 in all the treatments. Vitamin $C$ ranged from 21.86 to 38.44 in $T_{0}, 16.89$ to $35.76,17.89$ to 36.56 and 17.45 to 34.87 in $T_{1}, T_{2}, T_{3}$ respectively. Maximum concentration 30.81 was observed in $T_{0}$ and minimum concentration was observed in $\mathrm{T}_{3}$ during storage.

\section{Sensory evaluation}

Mango leather prepared by using skim milk and sucrose evaluated for different attributes like colour, flavour, texture, taste and overall acceptability by using hedonic scale after $0,15,30,45,60$ and 75 days (Hooda and Jood, 2005) and treatment effect as shown in Tables 4 and 5.

\section{Colour}

First point of products identity is its color that often predicts the consumer's acceptability and degree of satisfaction. The statistical analysis indicated that color was nonsignificantly affected by treatments, storage days and their interactions. The mean score of colour varied from 5.61 to 6.22 in all the treatments. Colour score ranged from 5.33 to 6.67 in $T_{0}, 5.67$ to $6.67,5.00$ to 6.67 and 5.00 to 6.67 in $T_{1}, T_{2}$ and $T_{3}$ respectively. Maximum colour score 6.22 was observed in $\mathrm{T}_{0}$ and minimum colour score 5.61 out of 9 was observed in $T_{2}$. The variance in colour score in $T_{0}$ was observed to be very low as compared to the other treatments during storage. $T_{2}$ recorded maximum marks during storage period.

\section{Flavour}

The statistical data from analysis of variance table indicated that flavour was non-significant affected by treatment, storage days and their interactions. The mean score of flavour varied from 5.61 to 6.06 in all the treatments. Flavour score ranged from 6.00 to 6.33 in $T_{0}$, 4.67 to $6.00,5.00$ to 6.00 and 5.00 to 6.00 in $T_{1}, T_{2}$ and $T_{3}$ respectively. Maximum flavour score was observed in $T_{2}$ and minimum flavour score 5.61 out of 9 was observed in $T_{1}$. The variance in flavor score in $T_{0}$ was observed to be very low as compared to the other treatments during storage. $\mathrm{T}_{2}$ recorded maximum marks during storage period.

\section{Texture}

Statistical data from analysis of variance table indicated that texture was non significantly affected by treatments, 


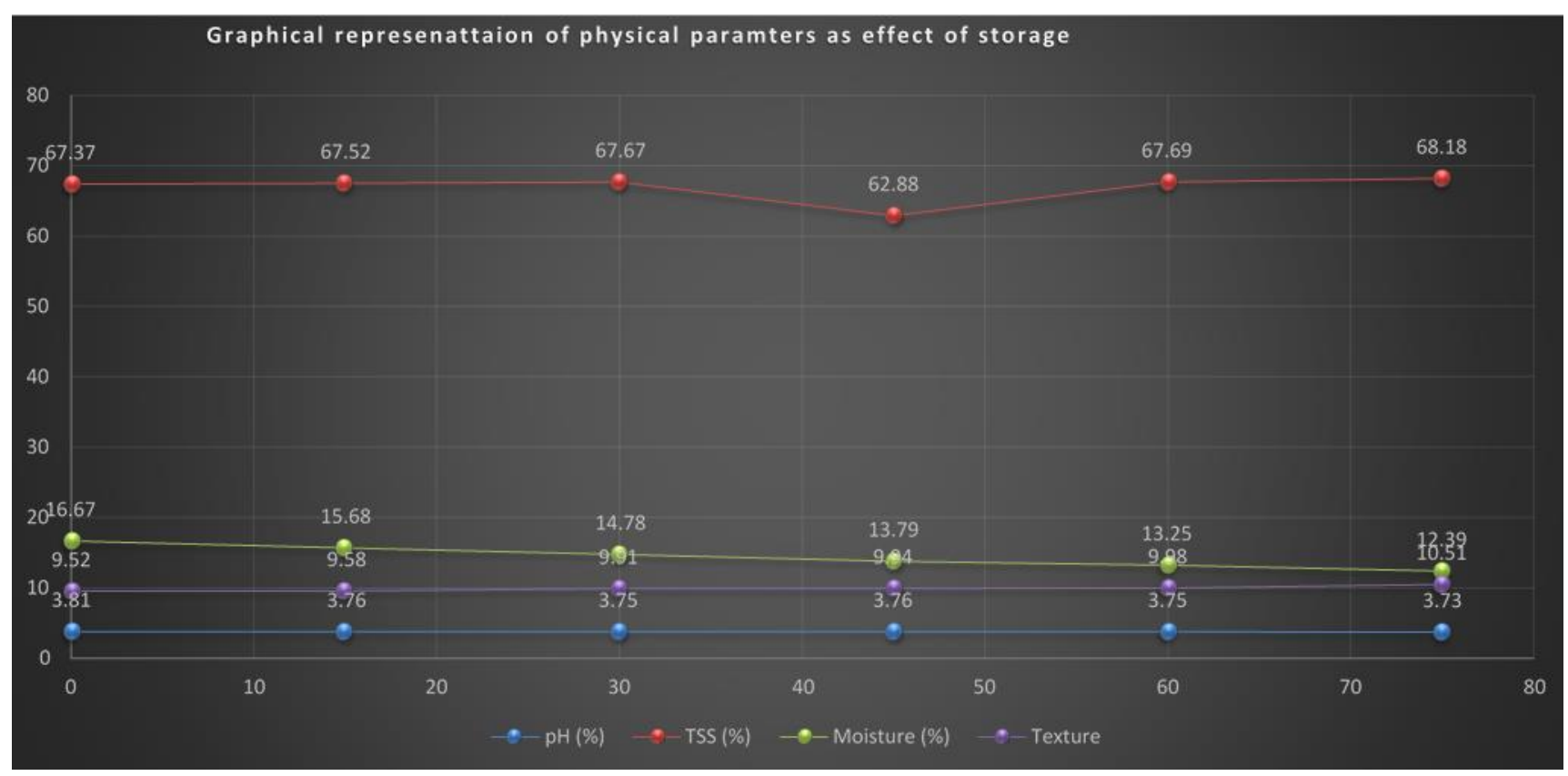

Figure 1. Graphical represenattaion of physical paramters as effect of storage.

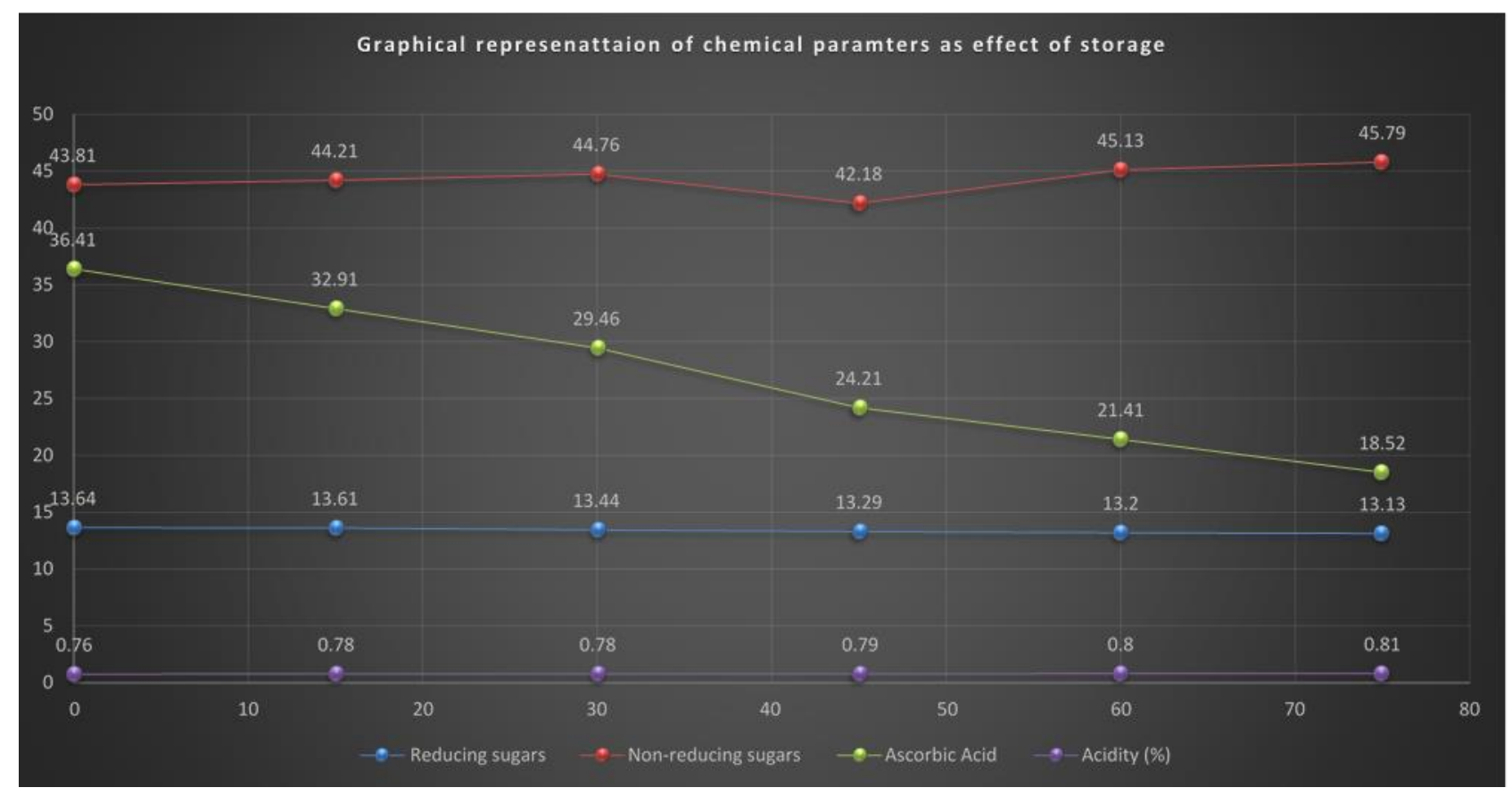

Figure 2. Graphical represenattaion of chemical paramters as effect of storage.

storage days and their interactions. The mean values of texture varied from 5.61 to 6.06 in all the treatments. Texture scores varied from 6.00 to 6.00 in $T_{0}, 4.67$ to 6.00 , 5.00 to 6.00 and 5.67 to 6.00 in $T_{1}, T_{2}$ and $T_{3}$ respectively. Maximum texture score 5.83 was observed in $T_{2}$ and minimum texture score 5.61 out of 9 was observed in $T_{1}$ which means that this treatment was not accepted by the sensory panel. The variation in texture score in $T_{0}$ was observed to be very low as compared to the other treatments during storage. $T_{2}$ recorded maximum marks during storage period. Mean score for texture varied from 5.61 to 6.06 in all treatments. 


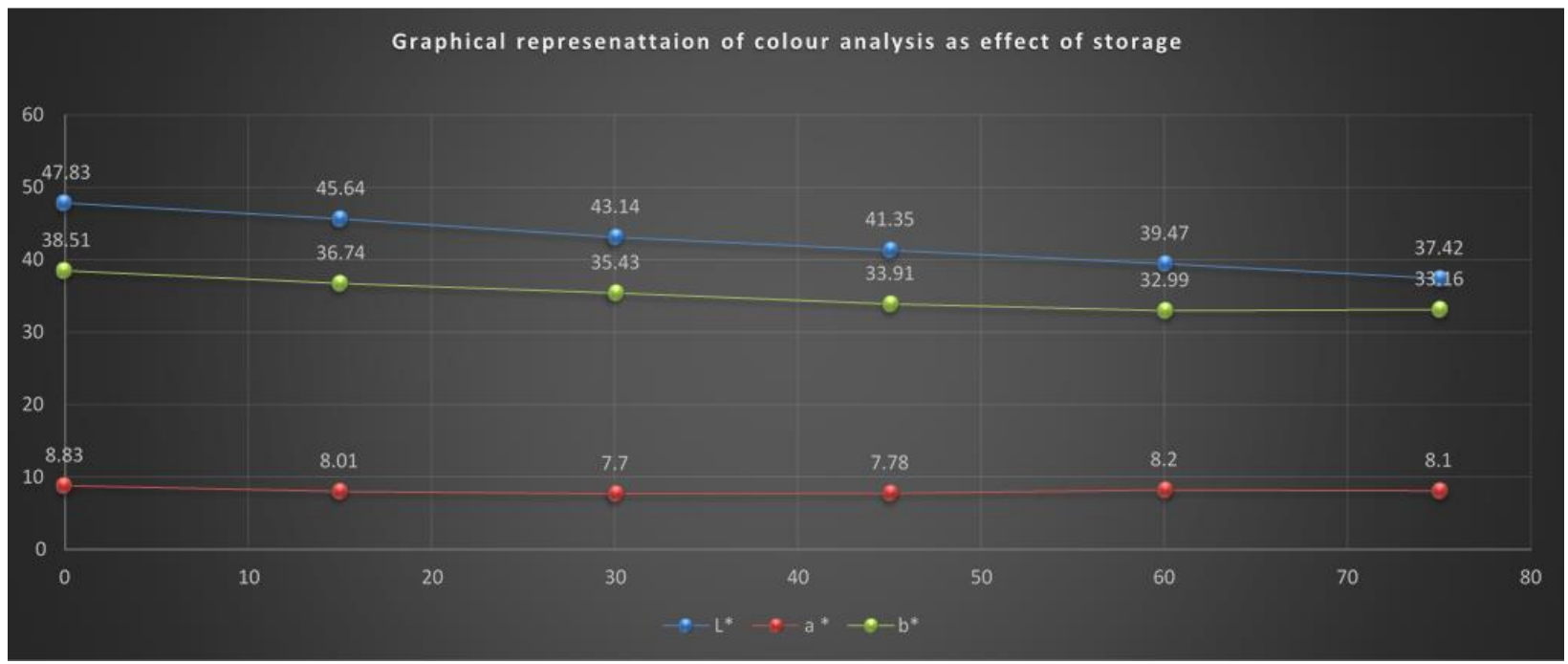

Figure 3. Graphical represenattaion of chemical paramters as effect of storage.

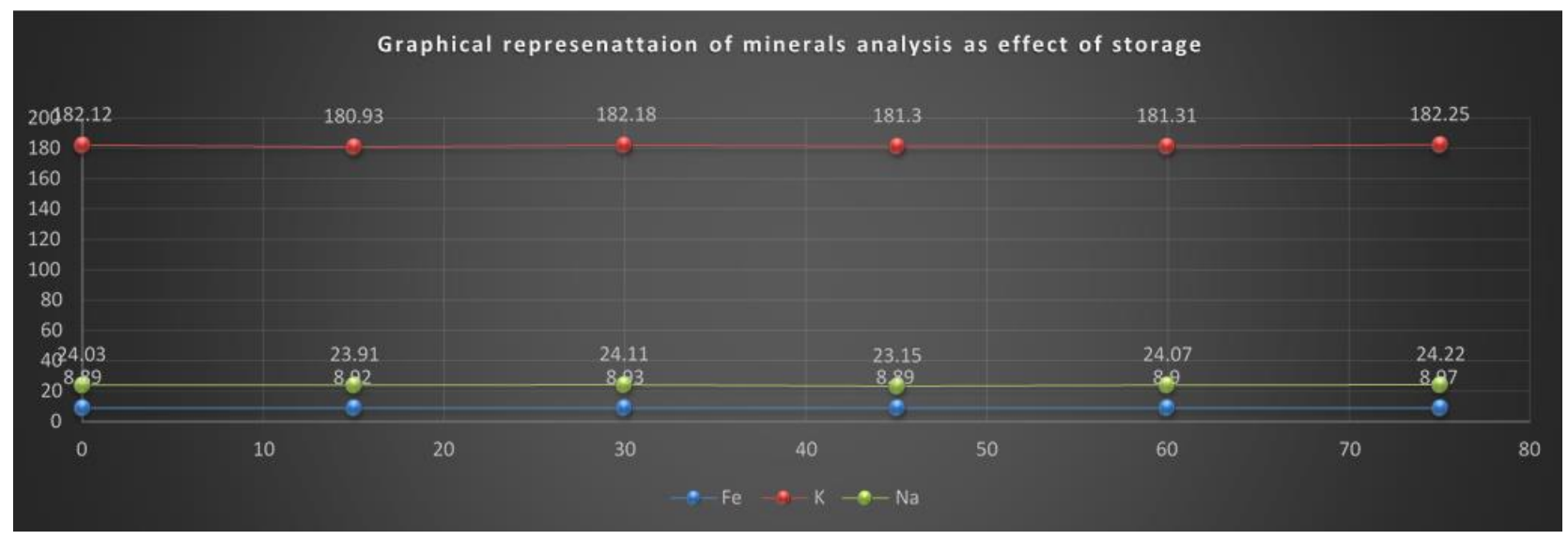

Figure 4. Graphical represenattaion of minerals analysis as effect of storage.

\section{Taste}

The statistical analysis indicated that taste was significantly affected by treatments while non-significantly affected by storage days and their interactions. The data regarding the mean score of taste varied from 4.9 to 5.9 in all the treatments. Best taste score was obtained (5.9) by T2 among all the treatments whereas 5.0, 5.1 and 4.9 was observed in T1, T0 and T3 respectively. In terms of storage days, minimum score (5.1) was observed at 30th whereas, 5.3 taste score was observed at $0,15,60$ and 75 th days of storage study.

\section{Overall acceptability}

The statistical data analysis pertaining to overall acceptability was not significantly affected by treatment, storage days and their interaction. The mean score of overall acceptability varied from 6.00 to 6.33 in all the treatments. Overall acceptability scored 6.0 in $T_{0}$ and $T_{2}$, while 6.06 and 6.33 was observed in $T_{1}$, and $T_{3}$ respectively. For storage days, maximum overall acceptability score (6.25) was observed at 0 day and minimum was reported at 15th and 30th day of storage study of mango leather by the sensory panel. Similar results have been reported by Manisha et al. (2011) and Kaushal et al. (2013) who studied acceptability of dried leather during the storage interval.

\section{Conclusion}

Pakistan produces fruits and vegetables on large scale but due to lack of proper processing facilities and value of poor chain, the export of fresh vegetables and fruits and processed products are less as compared to the other developing countries. Export of fruits and vegetables is 
less than $10 \%$ and postharvest losses are about 25 to $40 \%$.

The quality of fruit is most important parameter because mango is perishable fruit so it can deteriorate very easily. The demand of mango fruit is increasing day by day in all over the world due to their, delicacy, unique taste and their nutritional value. Fresh fruits and vegetables are recommended for better immune system. Fruit leather preparation is one of most important complementary treatment and food preservation technique in the processing of dehydrated foods, since it presents some benefits such as reducing the damage due to heat of flavour, colour, inhibiting the browning of enzymes and decrease the energy costs. Formation of mango leather leads towards increased consumption and availability throughout the year. Post-harvest losses can be minimized through value addition. Mango leather is an excellent substitute of synthetic candies. By adding skim milk powder the nutritive value of mango leather is increased due to incorporation of protein as fruits and vegetables are deficient in protein. Emerging technologies related to food processing and value addition should be adopted to minimize the postharvest losses.

\section{CONFLICT OF INTEREST}

The authors declare no conflict of interest.

\section{REFERENCES}

AOAC (2006). Official Methods of Analysis. The Association of Official Analytical Chemists. 18th Ed. Arlington, USA.

Azeredo, H., Brito, E. S., Moreira, G. E., Farias, V. L., \& Bruno L. M. (2006). Effect of drying and storage time on the physicochemical properties of mango leathers. International Journal of Food Science and Technology. 41:635-638.

Azeredo, H., Mattoso L. H. C., Wood, D., Williams, T. G., AvenaBustillos, R. J., \& Mchugh, T. H. 2009. Nanocomposite edible films from mango puree reinforced with cellulose nanofibers. Journal of Food Science. 74.

Chukwuka, K. S., Iwuagwu, M., \& Uka, U. N. (2013). Evaluation of nutritional components of Carica papaya $L$. at different stages of ripening. IOSR Journal of Pharmacy and Biological Sciences, 6(4), 13-16.

Dea, S., Jeffrey, K., Brecht, M., Nunes N., \& Elizabeth, A. B. 2010. Occurrence of chilling injury in fresh Kent Mangoes. Postharvest Biology and Technology, 57, 61-63.

Dea, S., Jeffrey, K., Brecht, M., Nunes N., \& Elizabeth, A. B. 2010. Occurrence of chilling injury in fresh Kent Mangoes. Postharvest Biology and Technology, 57, 61-63.

Diamante, L. M., Bai, X., \& Busch, J. (2014). Fruit Leathers: Method of Preparation and Effect of Different Conditions on Qualities. International Journal of Food Science, vol. 2014, Article ID 139890, 12 pages, 2014.

Durrani, A., \& Verma, S. (2011). Preparation and Quality evaluation of honey Amla Murabba. Journal of Industrial Research and Technology, 1, 40-45.

Gujral, H. S., \& Khanna, G. (2002). Effect of skim milk powder, soy protein concentrate and sucrose on the dehydration behaviour, texture, color and acceptability of mango leather. Journal of food engineering. 55:343-348.

Hawlader, M., Perera, C. O., \& Tian, M. (2006). Properties of modified atmosphere heat pump dried foods. Journal of Food Engineering, 74, 392-401.

Hooda, S., \& Jood, S. (2005). Organoleptic and nutritional evaluation of wheat biscuits supplemented with untreated and treated fenugreek flour. Food Chemistry, 90, 427-435.

Izli, N., Izli, G., \& Taskin, O. (2017). Influence of different drying techniques on drying parameters of mango. Food Science and Technology (Campinas), 37(4), 604-612.

Kaushal, M., Sharma, P. C., \& Sharma, R. (2013). Formulation and acceptability of foam mat dried seabuckthorn (Hippophae salicifolia) leather. Journal of Food Science and Technology, 50(1), 78-85.

Khan, M., Mustafa, K., Shah, M., Khan, N., \& Khan, J. Z. (2008). Forecasting mango production in Pakistan an econometric model approach. Sarhad Journal of Agriculture, 24, 363-369.

Kumar, R., Balaji, S., Uma, T. S. \& Sehgal, P. K. (2009). Fruit extracts of Momordica charantia potentiate glucose uptake and up-regulate Glut-4, PPARY and PI3K. J. ethnopharmacol. 126:533-537.

Memon, N.A. (2016). Mango: Pakistan 4th Largest Producer in the World. Ministry of National Food Security and Reseach, Government of Pakistan, Islamabad.

Moreno, J., Bugueño, G., Velasco, V., Petzold, G. \& TabiloMunizaga, G. (2004). Osmotic dehydration and vacuum impregnation on physicochemical properties of Chilean papaya (Carica candamarcensis). Journal of Food Science, 69.

Naz, R. (2012). Physical properties, sensory attributes and consumer preference of fruit leather. Pakistan Journal of Food Sciences. 22,188-190.

Ordóñez-Santos, L. E., Martínez-Girón, J., \& Arias-Jaramillo, M. E. (2017). Effect of ultrasound treatment on visual color, vitamin C, total phenols, and carotenoids content in Cape gooseberry juice. Food chemistry, 233, 96-100.

Piga, A., Catzeddu, P., Farris, S., Roggio, T., Sanguinetti, A., \& Scano, E. (2005). Texture evolution of "Amaretti" cookies during storage. European Food Research and Technology. 221:387-391.

Pushpa, G., Rajkumar, P., Gariepy, Y., \& Raghavan, G. (2006). Microwave drying of enriched mango fruit leather. 2006 ASAE Annual Meeting, American Society of Agricultural and Biological Engineers, 1.

Rababah, T. M., Al-Mahasneh, M. A., Kilani, I., Yang, W., Alhamad, M. N., Ereifej, K., \& Al-U'datt, M. (2011). Effect of jam processing and storage on total phenolics, antioxidant activity, and anthocyanins of different fruits. Journal of the Science of Food and Agriculture, 91, 1096-1102.

Riboli, E. \& Norat, T. (2003). Epidemiologic evidence of the protective effect of fruit and vegetables on cancer risk. The American Journal of Clinical Nutrition, 78, 559S-569S.

Steel, R. G. D., Torrie J. H., \& Dickey, D. A. (1997). Principles and procedures of statistics. A biometrical approach. 3rd Ed. McGraw Hill Book Co. Inc., New York

Tontul, I., \& Topuz, A. (2017). Effects of different drying methods on the physicochemical properties of pomegranate leather (pestil). LWT-Food Science and Technology, 80, 94-303.

Wall, M. M. (2006). Ascorbic acid, vitamin A, and mineral composition of banana (Musa sp.) and papaya (Carica papaya) cultivars grown in Hawaii. Journal of Food Composition and Analysis. 19, 434-445. 